\title{
The Shifting Feminine Statuses among Indigenous Peoples: Rethinking Colonization and Gender Roles among the WeppaWanno People of Mid-Western Nigeria
}

\author{
Michael 0. Nwalutu' ${ }^{1}$, Felicia I. Nwalutu ${ }^{2}$ \\ ${ }^{1}$ Social Justice Education, OISE, University of Toronto, Toronto, Canada \\ ${ }^{2}$ Department of History, University of Toronto, Toronto, Canada \\ Email: nwalutu@yahoo.co.uk
}

How to cite this paper: Nwalutu, M. O., \& Nwalutu, F. I. (2019). The Shifting Feminine Statuses among Indigenous Peoples: Rethinking Colonization and Gender Roles among the WeppaWanno People of Mid-Western Nigeria. Sociology Mind, 9, 168-182.

https://doi.org/10.4236/sm.2019.93012

Received: April 21, 2019

Accepted: June 10, 2019

Published: June 13, 2019

Copyright $\odot 2019$ by author(s) and Scientific Research Publishing Inc. This work is licensed under the Creative Commons Attribution International License (CC BY 4.0).

http://creativecommons.org/licenses/by/4.0/

\begin{abstract}
In this work we have argued that the post-independent WeppaWanno patriarchal system has evolved not from its cultural past but as influenced by the duo cultural tragedies implicated in Nupe Islamic invasion and the British/Christian colonial rule. Thus stirring the trajectory from the familiar approach of Western-focused critic of pre- and post-colonial Africa, this paper views the evolving manifestations of feminine and gender-roles in WeppaWannoland as flexible and varied with the positioning of community's cultural and socio-political experiences through the spectrum of Arabic, and Western colonial influences. The paper demonstrates using qualitative analysis, post-structural leaning, field interviews, and archival records, that while gender and class categories may be critical constituents of WeppaWannocosmology, flexibility of gender as a thought construct was far more important in most part of Africa in the definition of power, although such factors as achievement and ascription were essential.
\end{abstract}

\section{Keywords}

Gender Roles, Colonial, Perception, Invasion, Cultural Subversion

\section{Introduction}

Weppa-Wannoland is located on the western side of the River Niger, across the Igala kingdom. It is flanked in the west by Avianwhu, in the south by Ekperi, both Etsako clans, and in the north by Igbirraland. It is located between Latitude $6^{\circ} \mathrm{E}-7^{\circ} \mathrm{E}$ and Longitude $6^{\circ} \mathrm{N}-7^{\circ} \mathrm{N}$. The Amoya and Adegbe conceptions of female 
status in WeppaWanno were among those cultural heritages that have been subverted, and dislodged by the two major imperialist incursions that redefined the political, and therefore, the economic and socio-cultural history of WeppaWannoland. These were the Nupe/Islamic jihadist invasion and slave raids that took place in the first half of the nineteenth century; and the British/Christian colonial conquest and missionary incursions in the early twentieth century. In the cultural alterations sequel to invasions of WeppaWannoland by Nupe Kingdom and subsequently European colonialists, it is not difficult to decipher the distortions created by the two external destabilizing factors (Bello-Imam, 1995; Harunah, 2003; Nwalutu, 2004). The Adegbe and Amoya female statuses became the center of interest in this work considering the shift of WeppaWannoland from a typical matriarchal society to Western type patriarchal chiefdom. Weppa-Wannoland is located on the western side of the River Niger, across the Igala kingdom. It is flanked in the west by Avianwhu, in the south by Ekperi, both Etsako clans, and in the north by Igbirraland. It is located between Latitude $6^{\circ} \mathrm{E}-7^{\circ} \mathrm{E}$ and Longitude $6^{\circ} \mathrm{N}-7^{\circ} \mathrm{N}$. The Amoya and Adegbe conceptions of female status in WeppaWanno were among those cultural heritages that have been subverted, and dislodged by the two major imperialist incursions that redefined the political, and therefore, the economic and socio-cultural history of WeppaWannoland. These were the Nupe/Islamic jihadist invasion and slave raids that took place in the first half of the nineteenth century; and the British/Christian colonial conquest and missionary incursions in the early twentieth century, which eroded and systematically erased the Adegbe and Amoya binary feminity in the power dynamics of post-independent WeppaWanno society. This work draws attention not just to Adegbe status and its fading significance but the impact of foreign socio-cultural domination in gradually reducing the concept to a titular position, devoid of power and fame, which hitherto continues to breed chaos, disunity and legal battles in the society it originally served. Adegbe status is assigned all the even numbers of a family's daughters. In other words, every first, third, fifth etc. female children born in a family in Weppa-Wanno belong to the category, Amoya, while the second, fourth, sixth etc. are Adegbe. The positioning of Adegbe and her children in a complex status of power and preeminence over Amoya and often over their male brothers may have been a reenactment of female authority that existed in the community's early migration history. It is in the WeppaWanno traditional folklore that the dominant socio-political power in the history of WeppaWanno was wielded by the three traditional judges, who were deified women and their verdicts in any case were final. Questions guiding the thrust of this article are: How might we begin to re-theorize Adegbe as a waning feminine concept and position in a post independence WeppaWanno society? How did the Nupe/Islamic incursions and British/Christian colonization become the watershed in the distortion and eventual erasure of Adegbe power and influence in the community?

\section{Review of Literature}

In seeking to understand the implications of imperialism in complex reposi- 
tioning of female gender in WeppaWanno, we realized that although much has been written about gender formation, categorization and manifestation in Africa (Ogundipe-Leslie, 1994; Ngunjiri, 2010), little has been done to help in understanding the influence of Islamic and Western colonization on the repositioning of femininity and the depletion of power inherent in female positions as reflected in the contemporary Adegbe and Amoya statuses in WeppaWannoland. In addition, not much is documented that could expose how these external socio-political forces have worked to reconstruct and reshape both the masculine and feminine gender categories and power relations in indigenous African society. The superimposition of Islamic and Western norms, values and mores on WeppaWanno tradition, resulting from colonization supplanted the original male-female power balance, leaving at its wake Arabic cum Western type pseudo-patriarchy and socio-political chaos. In this paper, we would explore the terrain of gender reflected in the Adegbe and Amoya constructs in order to trouble the binary opposites in WeppaWanno construction of "femininity". This approach will expose the dynamics of power relations between the two female gender categories vis a vis their male counterpart in the pre-colonial WeppaWanno society and by so doing illuminate the disruptions that Islamic incursion and Western colonization constituted, specifically to the Adegbe positions of prestige and power.

We will proceed by reasoning that the practice of Adegbe "male daughter" position served to balance the male-female power relations in the pre-Nupe invasion and, therefore, pre-colonial WeppaWanno society. We will draw from Butler's notion of queer and gender performative, and Black feminist/ anti-colonial discourses to explore the gender and power relations of the two female categories and structures in the pre-colonial and post-colonial WeppaWanno societies with the view of understanding how the complex categorization and positioning of femininity transcended sex in the WeppaWanno practice. This, we hope, will illuminate the layered dimensions of shifts in the culture and traditions of the people as influenced by the double pressure of Islamic and Western incursions on WeppaWanno gender roles. In order to interrogate the processes of gender categorization and power relations in WeppaWanno, the following questions will guide the thrust of our work: How are the concepts of Adegbe and Amoya in the pre-colonial WeppaWanno related to balanced male-female power relations? How did Nupe invasion and British colonization disrupt, and reshape gender relations in WeppaWanno and at what social cost? We will be analyzing a large collection of primary data, based on ethnographic field research carried out in WeppaWannoland between 2002 and 2004. We will incorporate published materials from the region, as well as materials from feminist and post-structuralist thought in this analysis.

\section{WeppaWannoland: The People and Feminine Binary Opposites}

Pre-colonial Weppa-Wanno community assigned binary gender positions 
(based on traditions and customary positioning in birth) to their female children, a practice that also influenced how inheritance, title and power relations as well as forms of marriage was enacted and legitimized. This pre-colonial cultural practice is approved in the community and is hitherto extant however-in her post independent society-a watered down and waning reminiscence. The first position, Amoya in Weppa-Wanno affects all the odd numbers among the female children of a family. Adegbe status is assigned all the even numbers of a family's daughters. In other words, every first, third, fifth etc. female child born in a family in Weppa-Wanno belong to the category, Amoya while the second, fourth, sixth etc. are Adegbe. The positioning of Adegbe and her off-spring in a complex status of power and preeminence over Amoya, and often over their male brothers could be a reinvention and repositioning of female authority that existed in the community's early migration history. The migration narratives emphasized the dominant socio-political power wielded by the "three traditional judges" who were women and whose verdict in any case was final, namely: "Ikpeasegho, Emezualu and Otubutse" (Anaehomhe, 1980: p. 23; Nwalutu, 2004: p. 5). Such reinvention of female authority permeates all spheres of WeppaWanno cultural heritage. For instance the grand Ise shrine, housed in a large lake is dedicated to the female goddess, Ise whose chief priest, though a male, must assume a feminine status (both in dressing, hair-do and roles) as soon as he is installed to the throne of chief-priesthood, and is served by an all-male shrine servants.

It is often argued that while Ise is a symbol of spiritual feminine mother, and authority, Adegbe stands for the physical representation of that feminine authority in every family. She receives her portion of land and builds a house in her clan, just like her brothers; in fact Adegbe is a male daughter. By virtue of her birth positioning Adegbe performs "male" as a gender constructed by the society in which she lives. The Adegbe marriage is the union between a man and a woman obtained by the payment of a small dowry by the former. Male children of this union belong exclusively to the woman and the extended family of the woman, and the dowry or bride price paid on the daughters born from this union is divided equally between the husband's and the wife's families. This type of marriage contract entitles the man to the sexual relationship of his wife only. Often status of authority accorded Adegbe and her offspring in her paternal kindred (unlike in other Indigenous African communities) remains unattainable to her male peers all through her life. The assertion in Ogundipe-Leslie (1994) that it is within marriage that Nigerian women suffer the most oppression could be said not to apply to the pre-colonial Adegbe daughter. Ogundipe's exemplar points to the loss of privilege status by the female daughter or sister shortly after marriage. She reasons that with marriage, a daughter automatically transits to becoming a client or possession. She becomes voiceless and often right-less in her husband's family. Although Ogundipe's narrative tacitly describes the experience of an Amoya daughter in the pre-colonial and perhaps earlier part of the post-colonial WeppaWannoland. The reader would be puzzled to know that 
contrary to Ogundipe's view, an Adegbe enjoyed more privileges than her male siblings both in her father's home as a daughter and in her husband's home after marriage. One might at this juncture be tempted to ask why this binary treatment exists for female daughters of same parentage. In WeppaWanno only the Adegbe son for instance, is entitled to take out the Okhe title in his father's life time (Ajakwe, 2002; Ajegba, 2004). It is only the Adegbe son who can become an Obotsu (clan high priest) because titles can be made for them as soon as they are born and as such can rise to the rank of a priest (Obotsu) and qualified to hold the staff of that office, Akwi. The oldest Adegbe in her father's kindred and village is entitled to hold a priestly title called Oseghie and occupy a position known as Ekwi or Okwekwi. This position elevates her from the rank of a senior elder to that of a semi-deity in her life time and at death she joins the rank of village ancestors and ancestress. In this position, each year which begins with the Ukpe festival, she is expected to carry her Ubechi (a woven tray), a table and chair to the market place where she takes her place alongside the other male elders of the village. Women bring young children to her; she carries them and places them on her table, pronounces blessings on them and sets them down. In return the grateful mothers drop gifts on the tray (Campbell, 2001; Campbell, 2002; Charles, 2002; Emhoabino, 2003). Apart from this annual ritual, she exercises certain judicial rights over younger women in matters affecting marriages as well as distribution of cash and other items meant for the women. At death the Adegbe must be buried in her father's family and she is accorded every rite which her male counter-parts receive, without discrimination. The status of Amoya remains the same as ascribable to women in every other patriarchal society in Africa. She is a female daughter. The term Amoya also means the actual wife or "full marriage". This results from the payment of a full dowry by a suitor to the family of a female spouse. After the rituals of marriage are enacted she is incorporated into her husband's family or household and her children belong to his extended family (Amhofueshi, 2002; Akheonovao, 2002).

\section{Method of Data Collection}

What amazes every visitor to WeppaWannoland is not just the confluence of the geographical topographies of the various regions of the country in her serene atmosphere, but the vast Nigerian cultural heritages that found their ways into the cultural blend. We gathered data through qualitative field interviews and direct observations. As Indigenes of Eastern Nigeria, we employed the services of two indigenous interpreters who were arranged to guide us in the field. Our research spanned 2002 through 2004. As required by custom, we booked appointment and scheduled interview with the paramount chief, palace chiefs, the chief priests, the Lake guards, the Women leaders for Adegbe and Amoya women, the Okhe, and Obo title holders' cult heads, Ukpi and Akhe male and female drum-holders, the warrior groups and various age groups. Apart from the coronation activities of the new chief we were lucky to attend at his palace; the inter- 
views were held in different locations and live scenes. Captivated by her peculiar cultural space it was not difficult to observe as through a prism the distinct cultural colors of the various ethnic groups of Nigeria congealed in one cultural space. It was during the interviews that were an essential part of this research that we encountered the stunning dimension of peculiar WeppaWanno pre-colonial gender and power relations that are not just fast waning but leaves in its trail series of communal conflicts and court cases. We were attracted to investigate this aspect of WeppaWanno culture not only to contribute to the burgeoning literature on African feminism but because of its outstanding features that could be found in no other population in the six geo-political zones of Nigeria.

\section{Gender Performative, Adegbe versus Amoya Binary from the Lenses of Post-Structural and African Feminist Thought}

Judith Butler's notion of "gender trouble" and performativity will facilitate our understanding of issues at hand and closely link this work with the analysis of power relations-the power of discourse to produce that which it names-which is both a domain in which speech acts (and in this case, socially constructed position) evokes power and acts as a binder to the action performed. This approach is important in understanding the position, and interplay of power between Adegbe and Amoya in the pre-colonial WeppaWanno as both socio-cultural positioning of female subjects in which neither had any personal choice; and a site of power contestation between the two female gender categories on one hand and their male brothers on the other. In her work on gender trouble, Butler largely affirmed Joan Rieviere's essay on "womanliness as a masquerade" from which she (Butler) proceeds to argue that although Riviere postulated unity between gender attributes, a naturalized "orientation" appears as an instance of "imaginary formation" of sex. In her words, "Rieviere calls into question those naturalized typologies through an appeal to a psychoanalytic account that locates the meaning of mixed gender attributes in the "interplay of conflicts" (Butler, 1993: p. 50). By contrasting this psychoanalytic assumptions with one that would reduce the presence of ostensibly "masculine" attributes in a woman to a "radical or fundamental tendency" her work might have informed Butler's argument that "femininity is taken on by a woman who wishes for masculinity, but fears the retributive consequences of taking on the public appearance of masculinity". The Adegbe "masculinity" as a construct of her socio-cultural environment contrasts in a lot of ways. In the first instance, she reserved neither doubt nor fear of her identity, gender and sexual attribute. That does not mean she has desire for the phallus as the subject position that entails an active and heterosexualized desire. In other words, hers is the "mask" of the "women who wish for masculinity" that could be interpreted as an effort to renounce the "having" of the phallus. (p. 51). This enhances our understanding of the challenge that 
Amoya daughter levies on Adegbe in their annual Ukpe market-square debate in which she taunts Adegbe of enjoying male identity and its accruing power but denying the physical realities of maleness.

Secondly, Adegbe's position and privileges were, until incursion of foreigners into WeppaWannoland, a collective bequeathal and never an issue of individual psycho-social desires. Butler troubles gender in the realm of discourse as she interrogates the terms by which our identities are described, constituted and circumscribed. She adopts the Beauvoirian posture that gender is "not something one is but something one does" (Salih \& Butler, 2004: p. 90). The Adegbe female in pre-colonial WeppaWanno is a female masked as, and doing the masculine. The apparent irony of her social position as "strange" or queer is always beclouded by the power she wields both in her family and in the society at large. Since her position is socio-culturally constructed she learned the rituals of being and performing "Adegbe" (female-male). Her Amoya sister, to whom she appears both strange and superior, would pathologize, revere and debunk her titular position during their Ukpe festival market-square debate, by invoking a reminder that "Adegbe" daughter fits into neither of the prevalent gender categories of male and female (Amhofueshi, 2002; Akheonovao, 2002). Adegbe would respond to this challenge by reciting her masculine prowess, her amassed properties and the inherent power she wields. The pride and power of an Adegbe is inherent not in her name as an individual female but in her naturally and culturally imposed title. At birth during the pre-colonial times, Adegbe begins to learn the rituals peculiar to her position, and exhibit accumulation and dissimulating historicity of force (Butler, 1993). The employment of the title, Adegbe raises such questions as who is excluded by the usage of that term? And as Butler would ask, "for whom does the term present an impossible conflict between racial, ethnic, or religious affiliation and sexual politics?” (p. 19). Butler's use of drag as an example of gender performative acutely situates Adegbe as opposed to Amoya ("normal" female daughter) also as a performative of masculine gender.

Butler insists that "gender is performative insofar as it is the effect of a regulatory regime of gender differences in which genders are divided and hierarchized under constraint" (p. 21). One might be tempted to discountenance the words "under constraint" by claiming that Adegbe subjects are under no constraint to be Adegbe. But could she have become anything different if she wished to, given the social taboos, prohibitions, threats of punishment she would experience in ritualized norms peculiar to her socio-cultural environment? The repetition of learned norms in Butler's view constitutes the temporalized scene of gender construction and destabilization. But she also insists that gender is an assignment to the "extent it is never quite carried out according to expectation, whose addressee never quite inhabits the ideal s/he is compelled to appropriate" (Butler, 1993: p. 22). In other words, naming a female an "Adegbe" and "Amoya" initiates the process by which certain performances of these titular positions are compelled. No single sociological concept has attracted such a vast 
army of polemics as gender. The idea of male and female qualities being determined by biological notations (essentially, Western positivist perspective) was vigorously and somehow successfully challenged by behavioral scientists who believe that gender differences are socially acquired through cultural conditioning. Unlike Zevallos' (2016) reflections, which apparently forecloses platforms for dialectical engagements by focusing solely on Western gender discourses; Abaraonye (1997) reasons that gender experiences go beyond the experiences of our individual bodies and their functions in a social context to include shared social assumptions that derive from individual experiences. The latter apparently didn't subsume all cultures in a dominant Western paradigm. The term Adegbe or its symbolic power, in Butler's (1993) contribution, would govern the formation of a corporeally enacted feminity that never fully approximates the norm. At this juncture it is uncertain if the experience of a gendered psychic disposition or cultural identity is to Adegbe a conscious ambivalence of both a dignifying attainment or a site of struggle and resistance. This is because, although she enjoys the privilege the society confers on her as Adegbe, this subject position leaves her short of specific identification with respect to her sexuality, since the achievement requires a differentiation from the opposite gender. And "one is one's gender to the extent that one is not the other gender, a formulation that presupposes and enforces the restriction of gender within that binary pair" (Butler, 1993: p. 22). As drag is the sign of gender that is not the same as the body it figures, and which cannot be read outside of it, Adegbe remains both a signifier of distinctly "strange" category of gender, and a symbolic mask of male on a female body. It is actually the inherent power ascribed to this position by the socio-cultural mandate of the WeppaWanno people that impels her "female-daughter" sister, Amoya and their male brother to resist the contemporary Adegbe daughter, and at best challenge her power.

We will continue this discourse by incorporating African feminist and anti-colonial philosophies in order to chart a course for visualizing the impact of foreign incursions on WeppaWanno gender-power divides. The status of Adegbe in the pre-Nupe invasion and pre-colonial WeppaWanno society was a designation of prestige and power. So was her marriage which, unlike her Amoya sister, was a negotiation between equal partners in which she wielded stronger decision power. There were four attributes of power in the Weppa-Wanno society, namely: marriage, age, title and wealth. By her positioning in a titular Adegbe status, a female daughter and her offspring were inclined to gaining the other three. It is at this juncture important to accentuate that all Indigenous African socio-cultural relations are generally grounded in Indigenous African spirituality which in itself is a nexus of correlation and collaboration between the cosmic or metaphysical, the physical (including the flora and fauna) as they influence the affairs of human society. The pre-colonial Amoya female was the explicit symbol of the oppressed female category. The marginality and oppression experienced by the pre-colonial Amoya daughter (if any) was not ra- 
cial, but explicable in cultural gender and class constructs in the Indigenous WeppaWanno society. Being structured along the axes of gender and social class in pre-colonial WeppaWanno means also that the Amoya experienced oppression at the levels of personal biography (not just as a female, but involuntarily falling into the odd numbers of the family's female children); at the community level of cultural context and those of social institutions (Hill-Collins, 1990). Situations of internalized oppression, as experienced by the Amoya, was only understandable in traditional paradigm in which power as domination operates from the top down, by coaxing unwilling victims to bend to the will of the more superior. Patricia Hill-Collins reasons that this premise failed to account for "the willingness of the victim to collude in her own subjugation" (p. 225). This underscores the irony in Amoya's defense of her femininity, motherhood and "wifely" achievements at the Ukpe annual challenge with Adegbe. Implying that Amoya's hydra-headed site of oppression could well have served as her "sites of resistance" but for her cultural context (Foucault, 1982: p. 781). Since it is the culture that formed the ideas and molded experiences shared with community members, individual biographies are essentially rooted in these overlapping cultural contexts.

The only resistive effort recorded in WeppaWanno history and still being played out (as a historical reminiscence) is the public challenge between Amoya and the Adegbe groups during Ukpe (New Yam) festival in which each group verbally challenged the social acceptability of the opponent's conducts and status (Amhofueshi, 2002; Akheonovao, 2002; Nwalutu, 2004). It is not certain whether this event devolved from the pre-colonial experiences, however, it is astonishing that neither of these female groups, who presently have lost their positions and statuses to patriarchal subordination, could vent their tirades and challenges on their oppressor, their male counterparts who have been positioned and empowered by the British and to some extent, Islamic instruments of domination (Opara, 2000; Okeke-Ihejirika, 2004). Her position as a reproductive subject, economic aid and home builder left the Amoya female in the subordinate position described by Hill-Collins (1990) as the "interlocking processes of oppression" (p. 221). We must add, however, that the pre-colonial Adegbe daughters served to protect the Amoya daughters as sisters, mothers and as women married into their paternal and matrimonial homes. By so doing they served as effective checks on male oppressive controls and dominance. Adegbe and Amoya binaries thus become glaring exemplifiers of what Patricia Hill-Collins framed as a contradiction in the "matrix of domination", which failed to recognize that a matrix of domination contains few pure victims or oppressors (p. 228).

\section{How Islamic/Nupe Invasion and British/Christian Colonization Redefined and Reshaped Gender Relations in WeppaWanno}

In Nupe kingdom, the $19^{\text {th }}$ century witnessed a lot of wars for supremacy over the monopoly of trade with British merchant companies. For any part to win, 
they must have access to weapons of warfare, men of war and also be in the position to produce commodities for exchange. With the exception of Bello-Imam (1995), who reasons that "Nupe invasion which is a derivative from the Jihad of Uthman Ibn Fudio of the $19^{\text {th }}$ century is the antecedent and indeed precursor of the islamization of South Ibie people" (p. 97); other scholars believe that it was the commercial interests of British merchant capital that drove Bida slave raids into Weppa-Wannoland (Harunah, 2003; Anaehomhe, 1980; Nwalutu, 2004). And, like every other imperialist conquest, this was soon followed by religious cum cultural domination. To King Masaba of Nupe, the advantages of trade with the Europeans were so obvious, that a year after McCoskry's visit, Masaba was demanding muskets and gun powder from Baikie (Mason, 1981). The year after Baikie's departure in 1865, regular trade with the European trade ships began on the Niger. In reference to the volume of trade goods in that same year, 1865, Whitford, who had thought he would fill an European ship annually with ivory, palm oil, shea butter, lead ore (galena) and cotton, was surprised that the response he got to trade was beyond his imagination. He later wrote "we anchored off Eggan ... and in 3 weeks bought 5T. of ivory, 6T or $7 \mathrm{~T}$ of shea butter and several thousand country cloths; latter for sale on the coast" (Mason, 1981; Nwalutu, 2004; Oshomha, 1993). The development of slavery in Hausaland in our view was remotely connected to the demands of the world market. Every three years, Bida (Nupe) raiding force moved into Weppa-Wanno, usually in the dry season, and these invasions were consistent from about 1857-1895 when they were finally rebuffed by Weppa-Wanno local forces. The invading cavalry consisted of both males and females (the latter, disguised as males), all mounted on horse-back and armed with guns, swords and spears (Ajakwe, 2002; Ajegba, 2004). The villages were asked to submit specific number of persons or face a military action. When a village proved recalcitrant to these instructions, the villagers were harassed and in the ensuing confusion, some villagers were freely tracked down and taken captive. From 1861 onwards, EtsuMasaba's army became fiercer and more ruthless in their approach, burning down villages and looting their food stores. The result was severe cases of famine and epidemics. One may not altogether rule out the co-operation of local volunteers and accomplices during this frequent Nupe menace (Campbell, 2001; Ajakwe, 2002; Campbell, 2002; Charles, 2002; Emhoabino, 2003; Ajegba, 2004). They took the initiative to acquire slaves for exchange with the Nupe slave raiders. These partners also worked together in the procurement and final disposal of captives.

\section{Resistance to Nupe-Raids and Shift in Adegbe Power and Influence}

In about 1862, the Ukpi-drum (title-holders) in the entire community decided to confront the problem of incessant slave raids by the Nupe Islamic forces and possibly solve it through seeking audience with the Nupe Generals. They were told that the only option was for them to send human tributes once every three 
years to Bida. Some Ukpi drummers who complied sent children of the very poor and defenseless, and orphans. Those who refused took to their heels and deserted their towns and villages as the only option. By 1894, these attacks had become absolutely unbearable that some elders decided to fight back. One obvious feature of Nupe raids in Weppa-Wanno was its creation of a new set of social relations, patron-client relationship. The mighty and powerful dominated the weak and poor. Kinship idiom broke down almost completely to make room for patron-client deal in which the weak and poor depended on the powerful for protection in return for services rendered in form of agricultural labor. For the weak to continue living he had to attach himself or come into the protection of a powerful man by building his house right beside his and making his fence to touch his patron's wall. This also implied that the powers enjoyed by less noble men in WeppaWanno society (who were either classified as weak or unable to procure arms), and by extension Adegbe female, melted away into the protective embraces of the rich and powerful WeppaWanno warriors. Adegbe position henceforth became re-inscribed and reconstructed as "weak" and unmanly since they couldn't rise, arm themselves like strong male warriors and fight off the invaders. It was about this time also that the Okhe title assumed most of its privileges and dominant power in political, social, economic, and religious matters and gradually became the prerogative of the wealthy and powerful. Entry requirements also grew beyond the reach of the common masses making it possible for mostly titled men to afford to take out title for whomsoever they will. It should be emphasized at this juncture that the successful rebuff of Nupe invaders neither restored the Adegbe prestigious status and power nor extricated WeppaWanno cultural heritages from the stifling grip of Arabic culture which was introduced by Islamic Nupe Kingdom via peace treaties in earlier period of the invasion. For instance the society transited from pseudo matriarchal to patriarchy, and the social-power of all married women gradually devolved to their husbands. The indigenous position of Adegbe daughter was debunked and no longer was acceptable to some of the society members who converted to Islam. It was under this type of uncertain socio-political and economic atmosphere that the British chartered company-the Royal Niger Company-followed closely by the British colonial machinery and missionary groups made their way into Weppa-Wannoland in 1897.

\section{The Royal Niger Company, British Penetration of WeppaWannoland and Adegbe Socio-Political Woes}

The history of the Royal Niger Company is that of mergers, outbidding, and buying off of weak firms. In 1875, a liquidated Holland Jacques and company was bought by John Sendhouse Goldie Taubman, and his younger brother, George Goldie Taubman was put in charge (Bradbury, 1957; Bradbury, 1973). Out of this company a new one-the Central African Company was formed in 1876. In 1879, the United African Company was formed as an amalgamation of 
the West African Company, Miller Brothers, James Pinnock and the Central African Trading Company to check the threat of the French firm CompaigneFrancaise del' Afrique Equatoriale. In 1882 in order to expand its assets, a new company, the National African Company was floated which took the assets of the United African Company. It was the National African Company that obtained the charter in July, 1886 and changed its name to the Royal Niger Company Chartered and limited. The title for its chairman and Vice-chairman became Governor and Deputy Governor respectively, thus started the colonization of the various nations that later formed Nigeria.

The historicity of Weppa-Wanno imperialist experiences continue to point to two major external hegemonic incursions that hitherto influenced its socio-cultural life. But many social and cultural analysts deliberately or unwittingly prefer to focus only on Western colonization which definitely leaves a gap in the epistemic narrative. It is imperative to emphasize this in order to introduce a space for understanding the various systems and eras of transnational domination and their cultural implications for the victims of these onslaughts. European inter-state competition has been crucial to each phase of financial expansion and a major factor in the formation of those blocs of governmental and business corporations that have championed the capitalist world economy through its material expansion ploy. The Royal Niger Company, by 1896, began her penetration of the Weppa-Wanno towns and had as the priority the "total abolition of slavery" and all forms of enslavement in order to free labor from servitude. This is paramount to the company's goal of "buying cheap and selling dear" (Harunah, 2003: p. 412). The company had realized that if she must make profit, it would be easier for her to negotiate cheaper prices from small scale independent but numerous producers of palm oil, palm kernel and cotton than with few large client holders.

The devolution of leadership roles to male-only aristocrats which was sequel to Nupe invasion positioned four major holders of Ukpi chieftaincy drum and OwaIkhuthe shrine priest into WeppaWanno leadership. These also constituted the jury of final appeal in all WeppaWanno cases. It is evident from Isichei (1983), Achebe (2005); and Amadiume (1997), that throughout the region originally referred to as the Oil River Protectorate (which WeppaWanno was a part) prior to the amalgamation of Nigerian sub-regions into a country in 1914, both male and female indigenous peoples who were simultaneously victims of British domination were active in the struggle for socio-political power and autonomy. Since this was the socio-political situation on ground when the British invasion took place, the imperial administration, with major modifications, built on the existing socio-political structures, while sweeping cultural changes were enacted. In WeppaWanno therefore both genders were, in their various capacities involved in the resistance and struggles for independence, albeit, the efforts by the male pressure groups, activists and nationalist were given more media attention. The British defeat of the Bida emirate in 1897 and the liberation of slaves and 
captives henceforward, led to a tremendous increase of the Royal Niger Company's operations. Consequently the penetration of the British and their evangelizing mission also led to the "opening-up" of the hinterland and the search for new economic opportunities for British merchant, which eventually culminated in the opening of trading posts in Egori waterside by the Royal Niger Company. The Royal charter awarded to the Royal Niger Company empowered it to exercise all rights, interests, authorities and powers for the purpose of government (and the) preservation of public order (Nwalutu, 2004). The implication of this is that the Royal Niger Company maintained their own police force, a constabulary or military force, set up courts and impose taxes, as well as employed some WeppaWanno sons in the police force.

The establishment of mobile court in WeppaWannoland along Egori waterside, which heard cases in the Royal Niger Company's premises, marked the beginning of shift of power as the council of old Adegbe females never had to sit in judgement subsequently. Their position was supplanted by the British government and after independence, devolved to their male folks, under customary law, and inherited British legal systems prevalent in the country. The British interest in the Niger area was purely economical and borne on the wings of capitalist system of accumulation. The debunking of African concept of servant-leadership gave way to individualism and competition as is evident in every quarter in Western civilization today. Female power and societal roles in WeppaWanno, as in other colonized African nations, became "heavily marginalized and repudiated" (Ngunjiri, 2010: p. 169). In the traditional WeppaWanno society, as is the case in other African societies, the notion of leadership as solely the business of the gendered male category was alien because, to Africans, gender roles are complementary. The shift in power-relationship places an Adegbe female in a position where she must negotiate her place within the stipulated social order, as a subordinate of the male counterpart. Ogundipe (1994) shows that foreign incursion into African societies eroded many of the economic opportunities and social powers African women had held. This displacement is one of the bases for the contemporary Adegbe struggles to regain her position, right and privileges in WeppaWanno society.

\section{Conclusion}

We conclude therefore by arguing that the post-independent WeppaWanno patriarchal system has evolved not from its cultural past but as influence of the double cultural tragedies implicated in Nupe/Islamic invasion and British/Christian colonization. The traditional social structures that were mutual, gradually gave way to divergent Islamic, and Western practices that were patriarchal, distinctively hegemonic, dictatorial and more or less individualistic. As more and more indigenous family structures are redefined, and women are married in either the British (Christian), or Arab (Islamic) forms of marriages, Adegbe status gradually became a titular position, devoid of power and fame, 
and the condition is presently made worse when issues of denied inheritance or child custody are brought by an Adegbe daughter against her male siblings or spouse before the contemporary customary courts fashioned after the British patriarchal judicial system. In the dilemma that plays out Adegbe daughters are unable to access justice from the extinct traditional justice system that established them. This system is now replaced with English-type customary court that bears no relevance to the community it was meant for and on which the people repose no confidence.

\section{Conflicts of Interest}

The authors declare no conflicts of interest regarding the publication of this paper.

\section{References}

Abaraonye, F. I. (1997). Gender and Politics in Ibibioland 1900-1983: The Role of Ibidio Women (p. 353). PhD Dissertation, Lagos: University of Lagos. https://www.academia.edu/38670933/_Gender_and_Politics_in_Ibibioland

Achebe, N. (2005). Farmers, Traders, Warriors, and Kings: Female Power and Authority in Northern Igboland, 1900-1960, Social History of Africa. Portsmouth: Heinemann.

Ajakwe, M. (2002). Esakor East, Aganegbode-Owah-Ovao. Interview by Felicia Nwalutu and Michael Nwalutu. Translated by Cletus Izobo and Martin Otseme.

Ajegba, P. W. (2004). Etsakor East, Aganegbode, Aviodo-Ovao, Edo State. Interview by Nwalutu Felicia and Nwalutu Michael. Translated by Martin Otseme and Cletus Izobo.

Akheonovao, I. (2002). Etsakor East, Agenegbode, Edo State. Interview by Felicia Nwalutu and Michael Nwalutu. Translated by Martin Otseme and Cletus Izobo.

Amadiume, I. (1997). Reinventing Africa: Matriarchy, Religion \& Culture. New York: Zed Books.

Amhofueshi, I. (2002). Etsakor East, Agenegbode, Aghiere, Edo State. Interview by Felicia Nwalutu and Michael Nwalutu. Translated by Cletus Izobo and Martin Otseme.

Anaehomhe, A. (1980). The History of WeppaWanno. Auchi: Toba Printers.

Arrighi, G. (1994). The Long Twentieth Century: Money, Power and the Origins of Our Times. New York: Verso.

Bello-Imam, I. (1995). An Ethnographic Survey of South Ibie Clan of Etsako West Local Government of Edo State, Nigeria. Ibadan: Vantage Publishers.

Bradbury, E. (1973). Benin Studies. International African Institute. Oxford: University Press.

Bradbury, R. (1957). Ethnographic Survey of Africa, Western Africa Vol. 13: The Benin Kingdom and the Edo-Speaking Peoples of South-Western Nigeria. London: International African Institute.

Butler, J. (1993). Contingent Foundations: Feminism and the Question of "Postmodernism”. In J. Butler, \& J. W. Scott (Eds.), Gender Trouble: Feminism and the Subversion of Identity (pp. 3-21). New York: Routledge.

Campbell, C. (2001). Auchi, Edo North, Edo State. Interview by Felicia Nwalutu.

Campbell, C. (2002). Auchi, Edo North, Edo State. Interview by Felicia Nwalutu.

Charles, J. (2002). Etsakor East, Agenegbode, Owah-Ovao, Edo State. Interview by Felicia 
Nwalutu and Michael Nwalutu. Translated by Martin Otseme and Izobo Cletus.

Emhoabino, V. (2003). Uyo, Akwa Ibom State. Interview by Felicia Nwalutu. Translated by Cletus Izobo.

Foucault, M. (1982). The Subject and Power. Critical Inquiry, 8, 777-795.

https://doi.org/10.1086/448181

Harunah, H. (2003). A Cultural History of the Uneme: From the Earliest Times to 1962. Lagos: The Book Company Limited.

Hill-Collins, P. (1990). Black Feminist thought in the Matrix of Domination. In P. H. Collins (Ed.), Black Feminist Thought: Knowledge, Consciousness, and Politics of Empowerment (pp. 221-238). Boston: Unwin Hyman.

Isichei, E. (1983). A History of Nigeria. Essex: Longman Group Limited.

Mason, M. (1981). The Foundations of the Bida Kingdom. Zaria: Ahmadu Bello University Press.

Ngunjiri, F. (2010). Women's Spiritual Leadership in Africa: Tempered Radicals and Critical Servant Leaders. Albany: State University of New York Press.

Nwalutu, F. (2004). Weppa-Wannoland in Historical Perspective, Etsako East Local Government Area, Edo-North, Nigeria. Benin City: God's Heritage Communications.

Ogundipe-Leslie, M. (1994). Re-Creating Ourselves Africa Women \& Critical Transformations. Trenton, NJ: African World Press Inc.

Okeke-Ihekirika, P. (2004). Negotiating Power and Privilege: Igbo Career Women in Contemporary Nigeria. Athens, $\mathrm{OH}$ : Center for International Studies, Ohio University.

Opara (2000). The Concept of Otherness in African Feminist Thought. In M. Eboh (Ed.), Philosophical Criticisms: Anthropology of Gender Issues (p. 198). Port Harcourt: Pearl Publishers.

Oshomha, I. (1993). The Edo and Their Neighbors of M. Western Nigeria. Ibadan: New Era Publishers.

Salih, S., \& Butler, J. (2004). The Judith Butler Reader. Oxford: Blackwell Publishing.

Zevallos, Z. (2016). Sociology of Gender. Other Sociologist.

https://othersociologist.com/author/othersociologist 